ISOLATION OF POTASSIUM SOLUBILIZING ACTINOIMYCETES FROIM CERAMIC INDUSTRY SOILS

KEYWORD: Solubilization, Actinomycetes, Potassium, Fertilizer

\section{Sreeja Bopin*}

\section{Kalavati Prajapati}

DEPARTMENT OF MICROBIOLOGY, HVHP INSTITUTE OF POST GRADUATE STUDIES AND RESEARCH,KADI,(NORTHGUJARAT), INDIA, 382715 *Corresponding Author DEPARTMENT OF BIOTECHNOLOGY, PRAMUKH SWAMI SCIENCE AND H.D. PATEL ARTS COLLEGE,KADI, (NORTHGUJARAT), INDIA, 38275

Soil fertility and plant nutrition require an adequate management of essential macronutrients such as potassium (K) is mandatory for plant development. Potassium replenishment, particularly in smallholder agriculture, remains a challenge as it is mainly fertilizer dependent. While the user of soluble mineral potassium fertilizers is the obvious best means to combat potassium deficiency in soil, they were limited by high cost of fertilizers and availability at farmer's level. This research is to isolate and select potassium solubilizing soil Actinomycetes from ceramic industry soils. 22 Actinomycetes isolates were inoculated on Aleksandrov agar supplemented with $0.5 \%$ potassium aluminium silicate, isolates which gave the high ratio of clear zone were selected. Out of 22 Actinomycetes Isolates two (KSA 09 and KSA 16) were selected which gave highest solubilization in liquid medium by solubilizing insoluble potassium source i.e. feldspar.This two strain selected for further studies for future prospectus.

\section{INTRODUCTION}

Potassium (K) has been recognized as an essential element in intensive agricultural production systems and deficiency of $\mathrm{K}$ usually results in a decrease in crop yields. Potassium (K) is the major essential macronutrient for biological growth and development. Plants acquire potassium from soil as potassium ions. However, the concentrations of soluble $\mathrm{K}$ in soil are usually very low, and the biggest proportions of $\mathrm{K}$ in soil are insoluble rocks, minerals and other deposits (Goldstein, 1986 $\& 1994)$. In spite of that, these sources constitute the biggest reservoirs of $\mathrm{K}$ in soil under appropriate conditions, they can be solubilized and become available for plants. Microorganisms play a central role in the natural $\mathrm{K}$ cycle. There are considerable populations of K-solubilizing microorganisms in soil and in plant rhizosphere (Sperberg,1958). It is generally accepted that the major mechanism of mineral potassium solubilization is the action of organic acids synthesized by soil microorganism. Production of organic acids results in acidification of the microbial cell and its surroundings. Silicate bacteria were found to resolve potassium, silicon and aluminum from insoluble minerals (Aleksandrov et al. 1985).

Actinomycetes synthesize valuable bioactive compounds such as enzymes, antibiotics, neutraceuticals, antitumor agents, plant growth regulators and vitamins and also produce enzymes industrially (proteases, amylases, etc) (Prakash et al. 2013; Kamjam et al.2017:Wietzorrek and Bibb 1997; Shigeri et al. 2009). Actinomycetes are predominantly present in various natural habitats such as plant tissues as well as soil, thereby, have been isolated from various niches and production of extracellular hydrolytic enzymes by theses Actinomycetes confer them the properties of disease control and plant growth promotion. However, the applications of Actinomycetes as enzyme producers in agriculture field are relatively less explored (Rani.K, 2021). Actinobactes are able to thrive in extremely different soils, play important ecological roles in soil nutrient cycling and are recently being regarded as plant growth promoting rhizobacteria (PathomAree et al., 2006; Franco-Correa et al., 2010, Sun F., et al.2020).

\section{MATERIALS AND IMETHODS}

\section{Sample Collection}

Majority of the ceramic industries are using insoluble source of potassium i.e. feldspar as their raw material so samples were collected from the various ceramic industries. Total 15 samples were collected from different ceramic industries of Gujarat nearby Morbi, Meshana and Kadi region. The samples labelled as $\mathrm{S} 1$ to $\mathrm{S} 15$.

\section{Adaptation And Enrichment:}

Collected soil samples were mixed with insoluble potassium (Feldspar) and $\mathrm{CaCo}_{3}$ (for Actinomycetes growth) and incubated for 1 week at room temperature. After adaptation 1 $\mathrm{gm}$ of soil was inoculated in $100 \mathrm{ml}$ liquid medium containing $1 \%$ glucose, $0.05 \%$ yeast extract and $0.5 \%$ feldspar and incubated at $28+2^{\circ} \mathrm{C}$ on $120 \mathrm{rpm}$ for 1 week.

\section{Isolation and Screening of Potassium Solubilizing} Actinomycetes

Enriched samples were inoculated after serial dilution from $10^{-1}$ to $10^{-6}$ on Aleksandrov's agar medium constituted $1 \%$ glucose, $0.05 \% \mathrm{MgSo}_{4} .7 \mathrm{H}_{2} \mathrm{O}, 0.0005 \% \mathrm{FeCl}_{3}, 0.01 \% \mathrm{CaCO}_{3}$, $0.2 \% \mathrm{CaPo}_{4}$ and $0.5 \%$ potassium aluminium silicate, agar $3 \%$ pH-6.5 (Sugumaran and Janartham, 2007) and incubated at 28 $+2^{0} \mathrm{C}$ for 1 week. Colonies exhibiting clear zone of potassium solubilization were selected.

Secondary Screening was carried out on the basis of study of zone diameter of the different isolates by using Khandeparkar's selection ratio on same Aleksandrov's agar medium.

Ratio $=\mathrm{D} / \mathrm{d}=$ Diameter of zone of clearance $/$ Diameter of growth

To study the mechanism of potassium solubilization, selected Actinomycetes isolates were also inoculated on the same Aleksandrov's medium with $\mathrm{pH}$ indicator dye $(0.025 \%$ Bromothymol blue). (K B Prajapati, 2012)

Macroscopic/colonical And Morphologicak Characterization

Colony characteristics of the selected Actinomycetes strains were studied on Glycerol Asparagine Agar (GAA) medium. Cell morphologies of the isolates were observed using a compound microscope after performing Gram staining (H. C. J.Gram, 1884).

\section{RESULTS AND DISCUSSION}

Colonies exhibiting zone of clearance on Aleksandrov's agar medium were selected as potassium solubilizers. Total 22 Morphologically distinct actinomycetes colonies were selected and labeled as KSAl to KSA22 (Table 1). Isolates shows higher ratio of potassium solubilization by Khandeparkar's selection ratio were selected, i.e. KSA9, $\mathrm{KSA} 10, \mathrm{KSA} 12, \mathrm{KSA} 16$ and KSA 17 (table 2). 


\begin{tabular}{|c|c|c|c|c|c|c|c|}
\hline Isolates & $\begin{array}{l}\text { Diamet } \\
\text { er of } \\
\text { zone of } \\
\text { cleara } \\
\text { nce (D) } \\
\text { mm }\end{array}$ & $\begin{array}{l}\text { Diam } \\
\text { eter of } \\
\text { growt } \\
\text { h (d) }\end{array}$ & $\begin{array}{l}\text { D/d } \\
\text { (rati } \\
\text { o) }\end{array}$ & $\begin{array}{l}\text { Isolat } \\
\text { es }\end{array}$ & \begin{tabular}{|l} 
Diamet \\
er of \\
zone of \\
clearan \\
ce (D) \\
mm
\end{tabular} & \begin{tabular}{|l|} 
Diam \\
eter \\
of \\
growt \\
h (d)
\end{tabular} & $\begin{array}{l}\text { D/d } \\
\text { (rati } \\
\text { o) }\end{array}$ \\
\hline KSA01 & 09 & 09 & 1 & KSA12 & 11 & 08 & 1.37 \\
\hline KSA02 & 10 & 10 & 1 & KSAl3 & 10 & 09 & 1.11 \\
\hline
\end{tabular}

\begin{tabular}{|l|l|l|l|l|l|l|l|}
\hline KSA03 & 11 & 10 & 1.1 & KSA14 & 10 & 10 & 1 \\
\hline KSA04 & 12 & 12 & 1 & KSA15 & 10 & 09 & 1.11 \\
\hline KSA05 & 09 & 08 & 1.13 & KSA16 & $\mathbf{1 3}$ & $\mathbf{0 8}$ & $\mathbf{1 . 6 2}$ \\
\hline KSA06 & 10 & 10 & 1 & KSA17 & $\mathbf{1 0}$ & $\mathbf{0 8}$ & $\mathbf{1 . 2 5}$ \\
\hline KSA07 & 11 & 11 & 1 & KSA18 & 11 & 11 & 1 \\
\hline KSA08 & 09 & 08 & 1.13 & KSA19 & 10 & 10 & 1 \\
\hline KSA09 & $\mathbf{1 4}$ & $\mathbf{0 9}$ & $\mathbf{1 . 5 6}$ & KSA20 & 11 & 10 & 1.1 \\
\hline KSA10 & $\mathbf{1 1}$ & $\mathbf{0 8}$ & $\mathbf{1 . 3 7}$ & KSA21 & 12 & 12 & 1 \\
\hline KSA11 & 10 & 10 & 1 & KSA22 & 09 & 08 & 1.13 \\
\hline
\end{tabular}

Table-2. Potassium solubilizing Actinomycetes Isolates Description (colony morphology, microscopic features)

\begin{tabular}{|c|c|c|c|}
\hline Isolate no. & Description (colony morphology, microscopic features.) & Growth at GAA medium & Microscopic view \\
\hline KSA09 & $\begin{array}{c}\text { Aerial mycelium cream, smooth, powdery, circular, } \\
\text { colony reverse off white } \\
\text { Filaments branched. }\end{array}$ & & \\
\hline KSA10 & $\begin{array}{l}\text { Aerial mycelium gray, rough, powdery, circular, colony } \\
\text { reverse gray } \\
\text { Filaments branched. }\end{array}$ & & \\
\hline KSA12 & $\begin{array}{c}\text { Aerial mycelium brown, rough, irregular, colony reverse } \\
\text { brownish pigment } \\
\text { Filaments branched. }\end{array}$ & & \\
\hline KSA16 & $\begin{array}{c}\text { Aerial mycelium dark yellow, smooth, circular, reverse } \\
\text { light yellowish pigment producer } \\
\text { Filaments branched, }\end{array}$ & & \\
\hline KSA17 & $\begin{array}{c}\text { Aerial mycelium creamy, smooth, irregular, colony } \\
\text { reverse off white, } \\
\text { Filaments branched. }\end{array}$ & & \\
\hline
\end{tabular}

No reports found for Potassium solubilizing Actinomycetes, but the research suggested that microbixal solubilization of mineral phosphate might be either due to the excretion of organic acids causing acidification of the external medium or to the excretion of chelating substances (such as sideropshores) that form stable complexes with phosphate adsorbents (aluminium, iron and calcium) (Whitelaw, 1999, Welch et al.2002;Hamdali et al.2008)

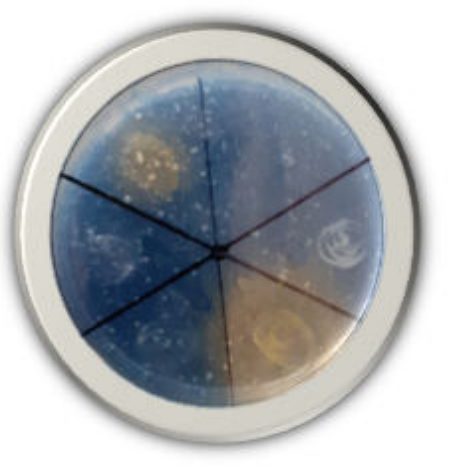

Figure 1. Zone Of Potassium Solubilization Aleksandrov + Btb Agar Medium.
Five selected Actinomycetes isolates showed low pH associated with yellow colour formation on the Aleksandrov's agar medium supplemented with Bromothymol blue after $72 \mathrm{hrs}$ of incubation indicates that $\mathrm{K}$ solubilization was through acidification mechanism. The zone of Potassium solubilization with Bromothymol blue containing medium by KSA09 \&KSA 16 (Fig-land 2).

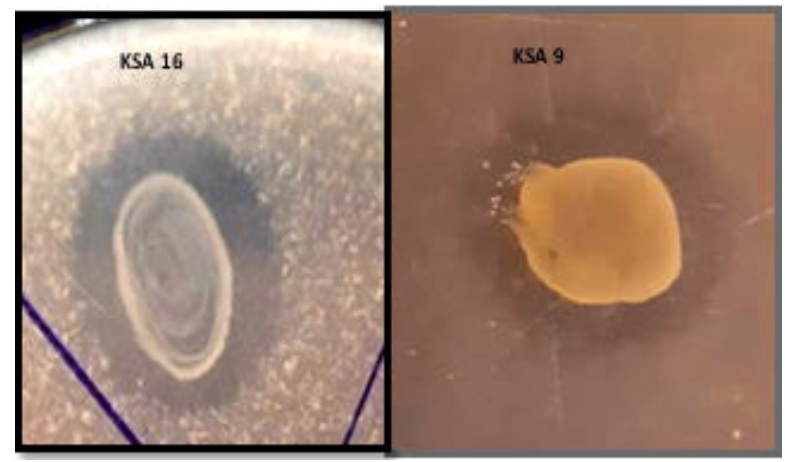

Figure-2. Zone Of Potassium Solubilization By Actinomycetes Isolates On Aleksandrov's Agar Medium By Ksa9 And Ksa16 Isolates. 
Many microorganisms have been found to possess this $\mathrm{K}$ releasing ability, e.g. Pseudomonas, Burkholderia, Acidithiobacillus, Bacillus mucilaginosus, $B$. edaphicus and $B$. circulans, etc. (Lian et al. 2002; Sheng 2005b; Zhao et al. 2008, Sugumaran and Janartham, 2007). Actinomycetes are widely distributed in many natural habitats including various soil, freshwater, marine, organic matter. Generally actinomycetes are neutrophiles, a few actinomycetes such as Streptomyces acidiphilus and members of the genus Streptacidiphilus5 have been reported to require acidic conditions ( $\mathrm{pH}$ 2.6-5.5) for growth(Jenson 1928, Kim et al 2003).

\section{CONCLUSION}

Total 22 Actinomycetes strains were isolated from various $\mathrm{K}$ rich ceramic industries soil samples. All the isolates were characterized for morphological and cultural characters.Among them 5 Actinomycetes isolates were selected for further study due to their higher potassium solubilization capabilities. All the isolates were able to solubilize (feldspar) insoluble potassium mineral under in vitro condition. Further two Actinomycetes strains i.e.KSA 9 and KSA 16 were selected which showed the highest zone of potassium solubilization on Aleksandrov's agar medium. Selected actinomycetes isolates showed low $\mathrm{pH}$ associated with yellow colour formation on the Aleksandrov's Agar medium supplemented with bromothymol blue indicates that potassium solubilization is due to acid production. Actinomecetes species play a major role in biogeochemical cycles so our selected potassium solubilizing actinomycetes could be used for development and formulation of new technology for non polluting farming practices and Biofertilizer.

\section{REFERENCES}

1. Alexander M. (1985) "Introduction to Soil Microbiology".John Wiley and Sons Inc., New York, USA. 382-385.

2. Franco-Correa M, Quintana A, Duque C, Suarez C, Rodriguez MX, Barea J-M (2010). "Evaluation of actinomycete strains for key traits related with plant growth promotion and mycorrhiza helping activities". Appl. Soil Ecol. 45:209217

3. Goldstein, A.H. (1986)"Bacterial solubilization of mineral phosphates: historical perspective and future prospects". American Journal of Alternative Agriculture 1,51-57.

4. Goldstein, A.H. (1994)"Involvement of the quinoprotein glucose dehydrogenase in the solubilization of exogenous mineral phosphates by gram-negative bacteria. In Phosphate in Microorganisms" Cellular and Molecular Biology, eds. ASM Press:Washington, DC, USA, 1994;pp. 197-203

5. Gram, H. C. J. (1884) "About the isolated staining of the schizomycetes in cut andDry Preparations ".Advances in Medicine, Berlin, 2: 185-189.

6. Hamdali, H., Bouizgarne, B., Hafidi, M., Lebrihi, A., Virolle, M.J, Ouhdouch, Y. (2008). "Screening for rock phosphate solubilizing Actinomycetes from Moroccan phosphate mines". Appl. Soil Ecol.,38:12-17https://doi.org/10. 19045/bspab.2019.80124.

7. Jensen, H. L. (1928).Actinomyces acidophilus n. sp. A group of acidophilus actinomycetes isolated from the soil. Soil Sci. 25, 225-236.

8. K.B.Prajapati and H.A Modi,(2012) "Isolation and Characterization of Potassium Solubilizing Bacteria from Ceramic Industry Soil" CIBTech Journal of Microbiology, 1(2-3):8-14.

9. Kamjam M, Sivalingam P, Deng Z et al (2017) "Deep sea actinomycetes and their secondary metabolites". Front Microbiol 8:760.

10. Kavita Rani, AtulParashar and LeelaWati, (2021)"'Estimation of hydrolyzing potential of chickpea actinomycetes for degradation of complex compounds through enzymes and acid production".The Pharma Innovation Journal 2021; 10(1):220-223

11. Kim, S., Lonsdale, J., Seong, C. \& Goodfellow, M. (2003). "Streptacidiphilus gen. nov., acidophilic actinomycetes with wall chemotype I and emendation of the family Streptomycetaceae emend. Antonie van Leeuwenhoek 83, 107-1 16

12. Lian B, Fu PQ, Mo DM, Liu CQ (2002) "A comprehensive review of the mechanism of potassium releasing by silicate bacteria". Acta Mineral Sin 22:179-183.

13. Pathom-aree W, Stach J, Ward A, Horikoshi K, Bull A, Goodfellow M (2006). "Diversity ofactinomycetes isolated from Challenger Deep sediment $(10,898$ m) from the Mariana Trench." Extremophiles. 10:181-189.

14. Prakash D, Nawani N, Prakash M et al (2013) "Actinomycetes: a repertory of green catalysts with a potential revenue resource". Biomed Res Int 2013:1-8.

15. Sheng XF (2005) "Growth promotion and increased potassium uptake of cotton and rape by a potassium releasing strain of Bacillus edaphicus". Soil Biol Biochem 37:1918-1922.

16. Shigeri Y, Matsui T, Watanable K (2009) "Decomposition of intact chicken feathers by a thermophile in combination with an acidulocomposting garbage-treatment process". Bio sci Biotechnol Biochem 73:2519-2521.

17. Sperberg, J.I. (1958)"The incidence of apatite-solubilizing organisms in the rhizosphere and soil". Australian Journal of Agricultural and Resource Economics 9, 778 .

18. Sugumaran $P$ and Janartham $B(2007$ ) "Solubilization of potassium minerals by bacteria and their effect on plant growth". World Journal of Agricultural Sciences 3(3): 350-355.
19. Whitelaw M.A(2000). "Growth promotion of plants inoculated with phosphate solubilizing fungi." Adv.Agron.69:99-144.

20. Whitelaw M.A. (1999) "Growth Promotion of Plants Inoculated with Phosphate-Solubilizing Fungi, Editor(s): Donald L. Sparks,Advances in Agronomy, Academic Press,Volume 69,Pages99to151.

21. Wietzorrek A, Bibb M (1997) "A novel family of proteins that regulates antibiotic production in Streptomycetes appears to contain an OmpR-like DNA-binding fold". Mol Microbiol 25:1181-1184. Zhao F, Sheng XF, Huang Z, He LY (2008) "Isolation of mineral potassium-solubilizing bacterial strains from agricultural soils in Shandong Province. BiodiverSci 16:593-60.TorrianiGorni A.,Yagil E. \&amp; Silver S. pp. 197-203 